\title{
地すべりの運動特性を考慮したリスクマネジメントに関する一考察 〜奈良県大塔村で発生した地すべり道路災害を例として〜
}

\author{
An analysis of landslide risk management on the basis of the movement characteristics \\ - On landslide disaster that caused damage to a highway in Ohto Village, Nara Prefecture -
}

\author{
野村康裕 ${ }^{\text {a) * } ・ \text { 藤澤和範 }}{ }^{\text {a) }}$ \\ Yasuhiro NOMURA, Kazunori FUJISAWA
}

\begin{abstract}
In this study, the authors analyzed the movement properties of landslides and the characteristics of damage by investigating the damage to highways during a landslide in Ohto Village, Nara Prefecture, for which precise data until the landslide was available, and applied the concept of risk management to landslide. The study showed that prediction of movement based on precise field surveys was effective for mitigating the damage by the landslide. The authors also pointed out that preliminary risk control is insufficiently recognized and proposed a flow for executing risk management. The landslide was estimated to have caused a loss of about 1.5 billion yen in the regional tourist industry by an indirect effect of damage by rumors, showing that indirect effects are serious as well as direct effects in risk management of landslide.

Key words : landslide, movement characteristics, risk management, indirect effect
\end{abstract}

\section{和文要旨}

本研究は，滑落までの調査デー夕の揃った奈良県大塔村で発生した地すべりによる道路災害を例に，地すべり現象の運動特性と 災害の特徵を整理し, リスクマネジメントの概念を地すべりへ適用した。災害発生後の危機管理としての地すべり被害軽減には, 綿密な現地調査に基づく崩壊予測が有効であることを示した。現状では事前のリスク管理の認識が希薄であることを指摘し，地す ベりリスクマネジメントの実施フローを提案した。地すべり災害の間接的影響の 1 つである風評被害による周辺地域の観光損失を 約15億円と試算し，直接的影響に加えて間接的影響も地すべりリスクマネジメントの重要な要素であることを示した。

キーワード：地すべり，運動特性，リスクマネジメント，間接的影響

\section{1.はじめに}

2004年（平成16年）は台風等の影響により全国各地で 土砂災害が頻発し，地すべり災害も451件発生した（国 土交通省砂防部，2005）。また，平成10年の全国危険箇 所調查結果によると，地すべり危険箇所は21,308箇所に のぼる。経済的にも技術的にも制約のある中で地すべり 災害の社会的影響を最小化するためには, 事前に優先的 な対策箇所を選定し斜面毎に効果的な対策手法を実施し ていくことと，実際に発生した災害に対して効率的に対 応することが重要となる。一般的に，このような課題に 対応する一方策として，存在するリスクを評価し管理し ていくリスクマネジメントの概念が広く用いられている (池田, 2000)。

土砂災害全般のリスクマネジメントに関して, 亀田ら （2002）が現状と今後の課題について検討を加えており, 土砂災害の発生確率に基づくリスク評価の必要性を述べ ている。斜面崩壊のリスク評価に関しては, 降雨強度と 斜面崩壊発生の相関関係から斜面崩壞の発生確率を降雨 発生確率を元に設定し, 斜面崩壊のリスク評価を行う研 究 (小橋, 2003) やタンクモデルによる崩壊機構のモデ ル化を試みる研究（高橋ら，2003）が行われている。し

\footnotetext{
* 連絡著者/corresponding author

a ) 独立行政法人土木研究所土砂管理研究クループ

Sediment and erosion control research group, Public works research institute

于 305-8516 茨城県つくば市南原 1 番地 6

1-6. Minamihara, Tsukuba-city, Ibaraki-Prefecture, 305-8516, Japan
}

かし，地すべりは必ずしも降雨に連動せず（鈴木ら， 2005), 降雨発生確率と関連付けて地すべり災害のリス ク評価を行うことは現状では非常に難しいと言える。一 般的には, 地方自治体が地すべり危険箇所調查要領（建 設省土木研究所，1998）に基づき危険箇所調查を行い, 技術者の判断による定性的な点数付けで地すべりの危険 度評価を行うことでリスク評価を代替しているのが現状 である。

もう一つ地すべりに特徵的なのは，その運動特性であ る。地すべりは緩慢な動きの中で運動速度の増減を繰り 返しながら進行していくことが多く，崩壊等の他の土砂 災害に比べて，保全対象への影響期間が長期に及ぶ傾向 にある（日本地すべり学会, 2002）。そのため, 避難生 活の長期化や道路など公共施設の復旧の遅れなどに伴い 社会活動への間接的影響は直接的な破壞による影響に比 ベて無視できないレベルにあると考えられる (Shuster, 1978）。このことは，地すべり災害の社会的影響の最小 化には間接的影響も考慮したリスクマネジメントの必要 性を示している。しかし，上野（2005）が間接的影響に ついても一部言及しているが，地すべりの間接的影響を 踏まえたリスクマネジメントはこれまでほとんど検討さ れていない。

そこで本検討では, 幸いにも変状の発見から滑落まで の間, 十分な調査データが得られている奈良県大塔村地 
すべりについて，運動特性と被害の特徵を整理し，リス クマネジメント手法の適用を試みた。

\section{2. 地すべりの概要}

平成16年 1 月下旬，奈良県大塔村宇井地区内国道 168 号の擁壁等に亀裂が発見され，6月下旬の台風 6 号に伴 う降雨により地すべり活動が活発化し始めた。その後も, 7 月下旬から 8 月上旬にかけて台風 10 号，11号による相 次ぐ降雨に見舞われ，本地すべりは 8 月 10 日に大規模滑 落を起こした（写真－1，2）。地すべりの変状が確認 されてから半年以上経ってのことであった。

対象地区は奈良県の内陸山間部に位置し，地すべり災 害は地域の基幹道路の国道168号に面する斜面で発生し た。斜面下方には上流に猿谷ダムを擁する熊野川が流れ ている（図－1）。国道168号は紀伊半島の中央を南北に 貫き，住民の生活道路の他，大都市圈と紀伊半島南部を 結ぶ長距離移動・輸送経路として重要な役目を果たして いた。また，平成16年 7 月に世界遺産に登録された熊野 古道等の貴重な観光資源が存在する地域でもある。対象

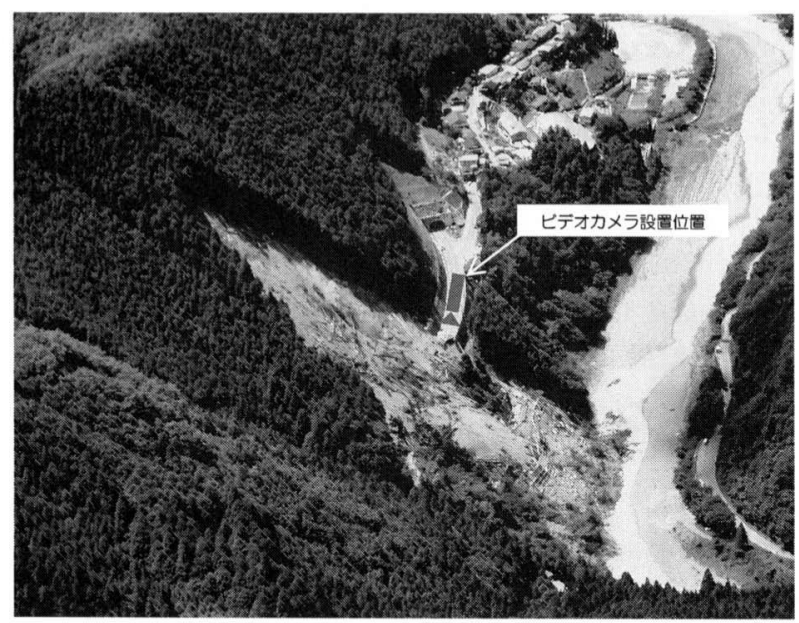

写真ー 1 滑落した宇井地区地すべりの全景（H16. 8. 14） Photo. 1 Panoramic view of Ui landslide that slipped down (August 14th, 2004)

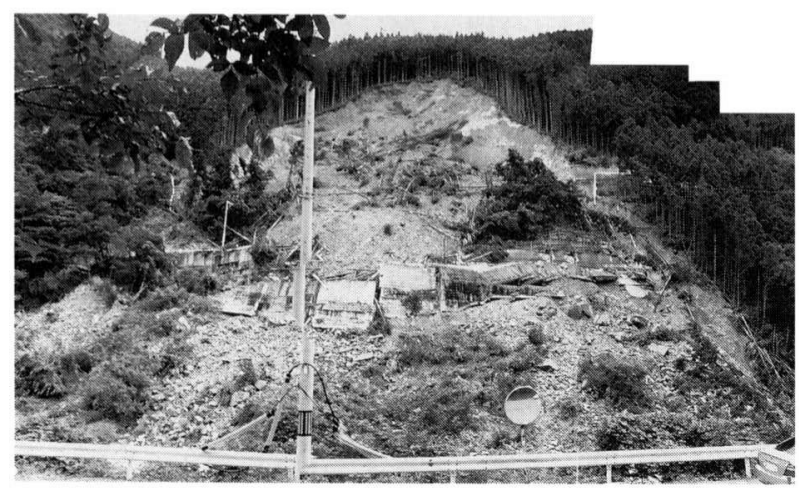

写真一 23 次滑落後の宇井地区地すべりの全景 (H16.8.13) Photo. 2 Full view of Ui landslide after third collapse (August 13th, 2004)
地区は地質的には四万十累帯に属し，チャート緑色岩を 伴う砂岩頁岩互層と砂岩層からなる地域に位置している (図 -2 )。

今回発生した地すべりの範囲は幅約 $120 \mathrm{~m} \times$ 長さ約 120 $\mathrm{m}$ に渡り, 滑落した土塊量は約 20 万 $\mathrm{m}^{3}$ と推定されるが, その大半が斜面下方の熊野川河川区域内に堆積し, 河積 の約30\%を阻害している状況を引き起こした。

\section{3. 滑落までの調査結果}

\section{1 地表面変状について}

筆者らは滑落前の 7 月 6 日, 滑落後の 8 月 14 日の 2 回 にわたり現地踏查を行った。7月 6 日の現地踏査におい て, 地すべりブロックの内部及び周辺部には多くの地す ベりに伴う変状が確認された。また, 滑落が起こる直前 にも奈良県による現地踏查が行われており，地すべり運

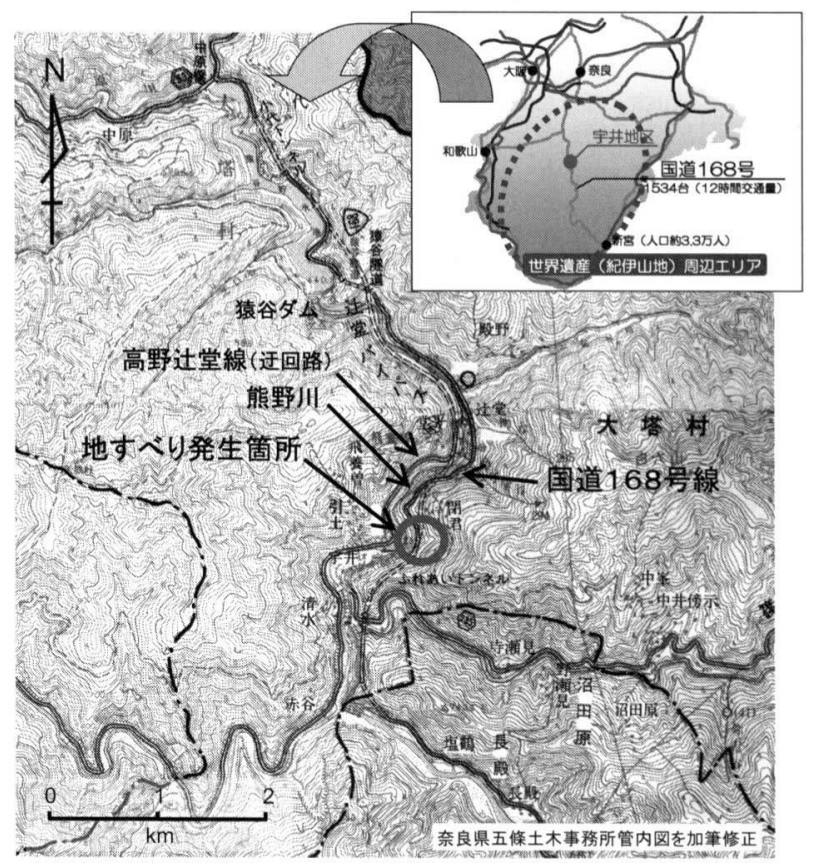

図一 1 調查地位置図

Fig. 1 Location of the study area

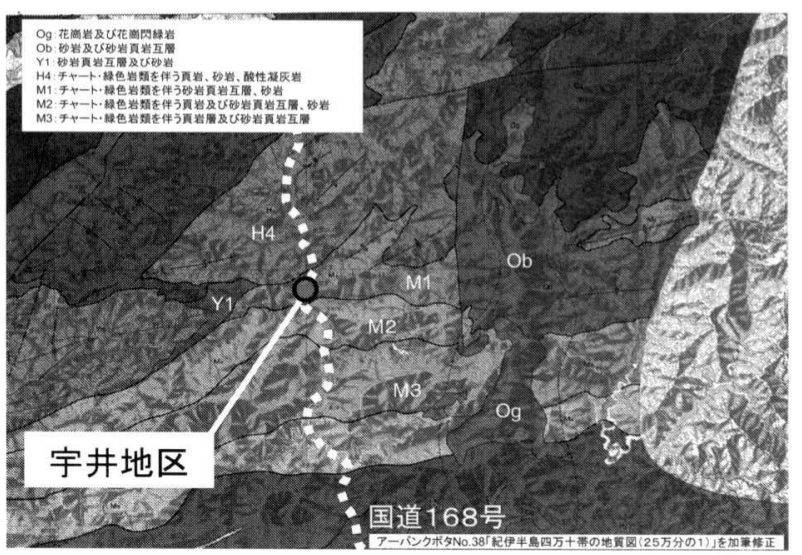

図－2 宇井地区周辺の地質図

Fig. 2 Geological map of the region surrounding Ui district 
動の活発化が地表の変状の進行状況からも確認されてい た。

\section{2 観測結果}

地盤伸縮計，パイプ歪計，ボーリング調査の結果につ いて説明する（図－3）。図－4に示す地盤伸縮計の変 動量のうち最も活発な変動を示している地すべりブロッ ク頭部のS- 6 について述べる。当初ほとんど累積変位 が見られない状態だったのが，5月中旬頃から $1.0 \mathrm{~mm}$ day程度の一定変位速度を示すようになった（1次ク リープ状態)。さらに 7 月下旬から 8 月上旬の台風 10 号,

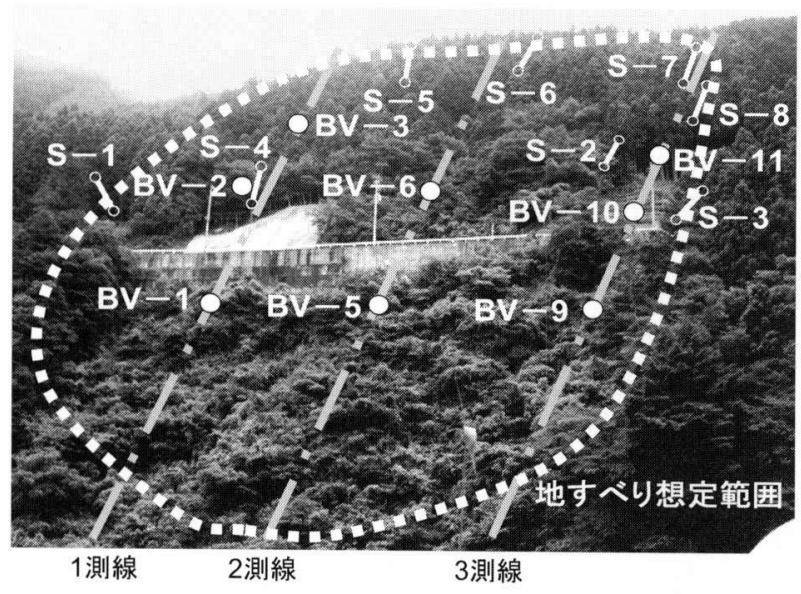

図一３＼cjkstart地すべり観測位置図

(S：伸縮計，BV：ボーリング調査孔）

Fig. 3 Location of observation points

(S : Extensometer, BV : Boring survey hole)

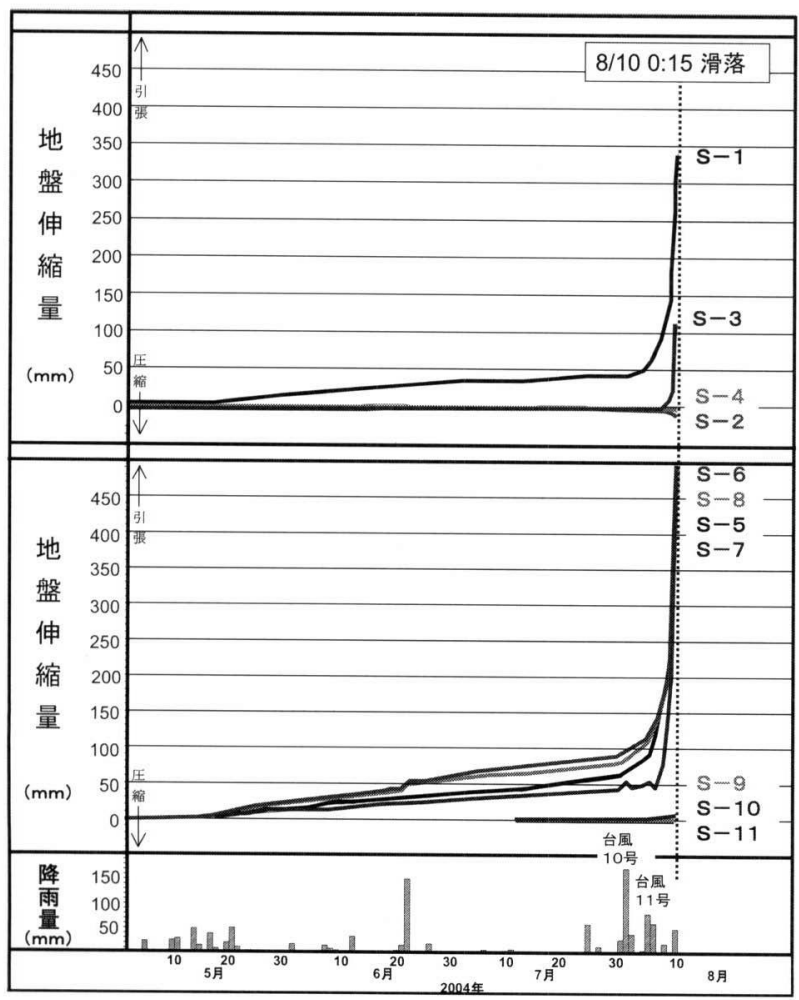

図－4 地盤伸縮計観測結果（図一 2，6 参照)

Fig. 4 Ground extensometer observation results
11 号に伴う総雨量約 $540 \mathrm{~mm}$ の降雨に対応して急激に変 位速度が増加し，8月 1 日〜 5 日の間， $4 \sim 6 \mathrm{~mm} / \mathrm{day}$ 程度で推移した（2 次クリープ状態）。8月 6 日からは 加速度的に増加を続けその後約 4 日間で滑落に至ってい る。このように斉藤（1968）の提唱するクリープ曲線に

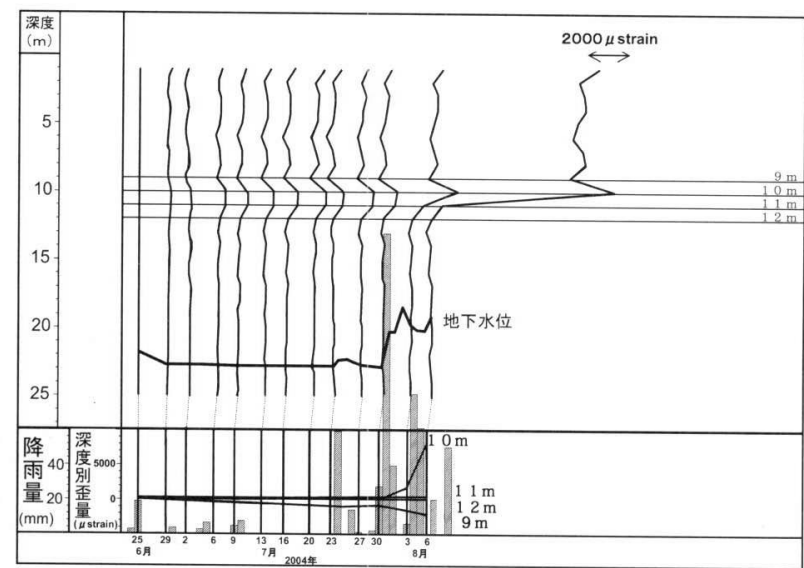

図ー5 パイプひずみ計観測結果（BV-10）

Fig. 5 Pipe strain gauge observation results (BV-10)

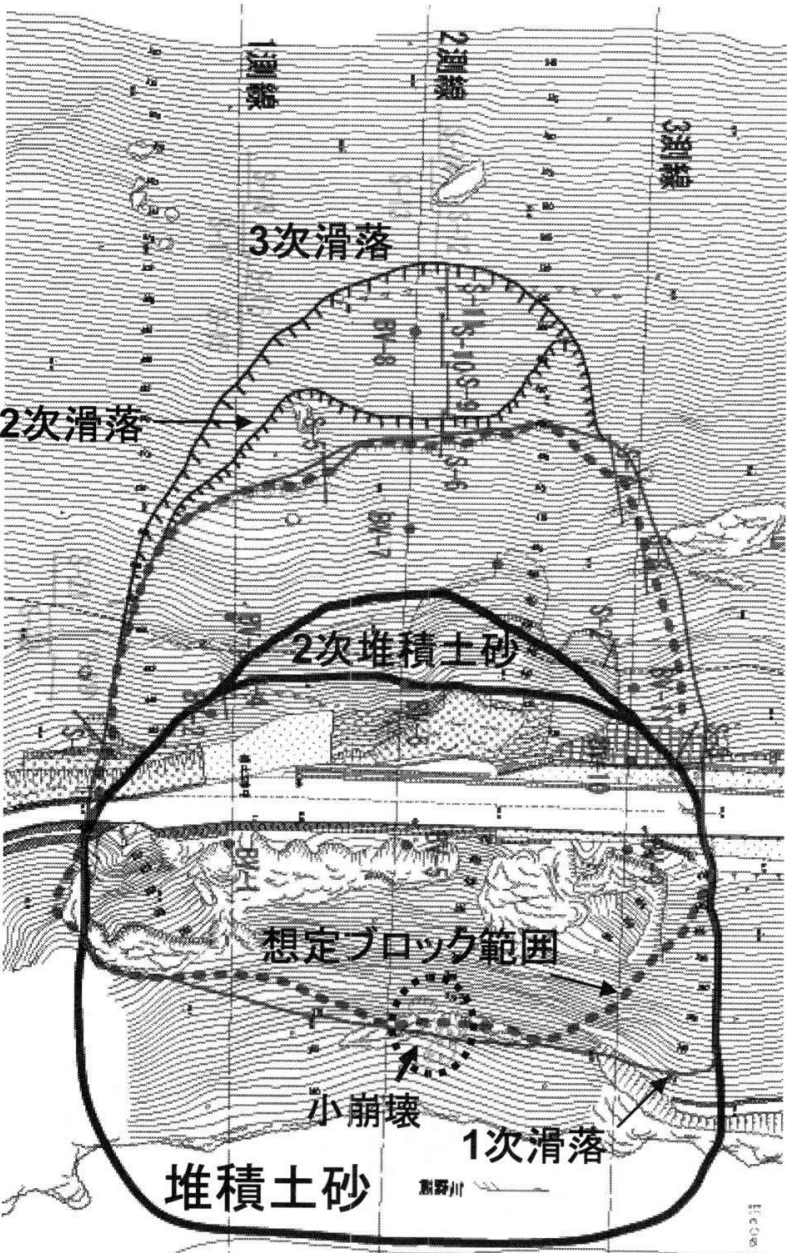

図一～地すべり滑落の過程とその範囲 Sは伸縮計，BVはボーリング調査孔

Fig. 6 Process of Ui landslide collapse and each collapse's extent 
近い破壊経路を示した。眓－５のパイプ歪計も降雨量の 増加, 地下水位の上昇に対応して急速に歪量を累積させ (深度約 $10 \mathrm{~m})$ ，滑落に至った様子を示している。また， ボーリング調查結果からすべり面は概称強風化部に相当 し，すべり面勾配は概ね砂岩と泥質岩の層理面に支配さ れていたと考えられる。これらの詳細については藤澤ら （2004）が報告している。

\section{3 滑落運動の解析結果}

滑落は, まず10日 0：15に大規模な 1 次滑落が発生し, 同日午前中に断続的な頭部滑落崖の小規模な 2 次滑落, 次いで 12 日 $22 ： 30$ に 3 次滑落，というように 3 段階に分 かれて発生し，滑落面はその度ごとに斜面上方へと後退 していった（図－6）。これは地すべりに多く見られる 特徵的な現象である（Varnes，1978）。近畿地方整備局 （2004）では写真－1 中に示す位置にカメラを設置し， 本地すべりの 1 次滑落を映像で捉えているが, この画像 を解析すると，斜面に向かって右側部の滑落速度は移動 開始 5 秒で最大速度約 $3.5 \mathrm{~m} / \mathrm{s}$ に達し, その約 15 秒後に

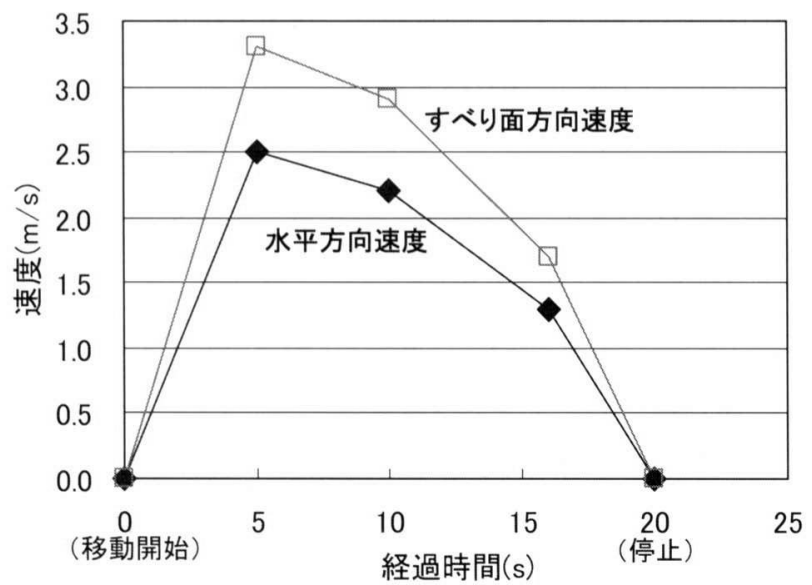

図ー7＼cjkstart地すべり土塊の滑落速度の変化

Fig. 7 Horizontal velocity of landslide collapse

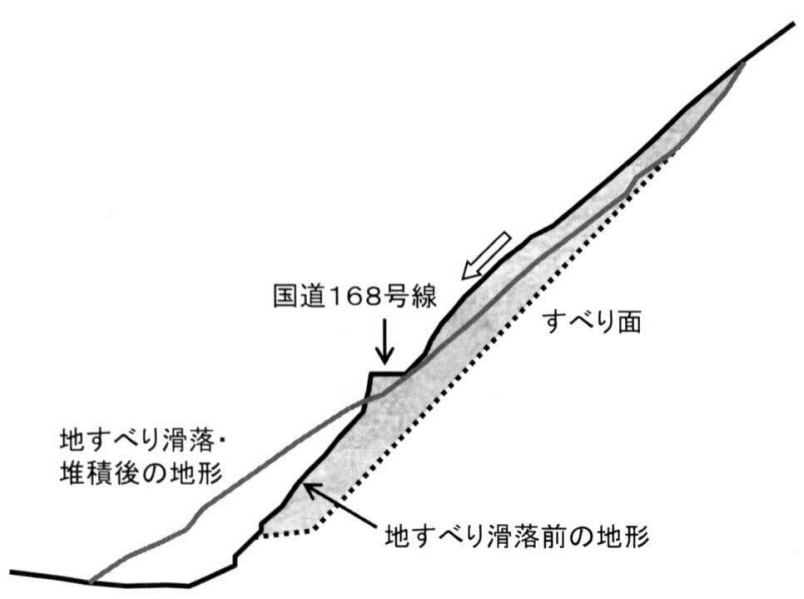

图－8３次滑落後の縦断面図と推定すべり面 (図一 3, 2 測線)

Fig. 8 Longitudinal section after collapse of the landslide and estimate sliding surface (measurement line 2 in Fig. 3)
停止する約20秒間の運動であったことが分かる(図－７）。 映像を見ると，立木が大きく傾斜することなく斜面下方 に滑り落ちている様子が観察されることからも，すべり 面が図ー8のようにほぼ直線状であったと推定できる。

\section{4. 滑落後の現地調查結果}

4.1 地すべりブロック範囲について

図ー6に示したように，3 次滑落の頭部は滑落前の調 查で斜面上方に変状が見られた最上部に相当し，地すべ

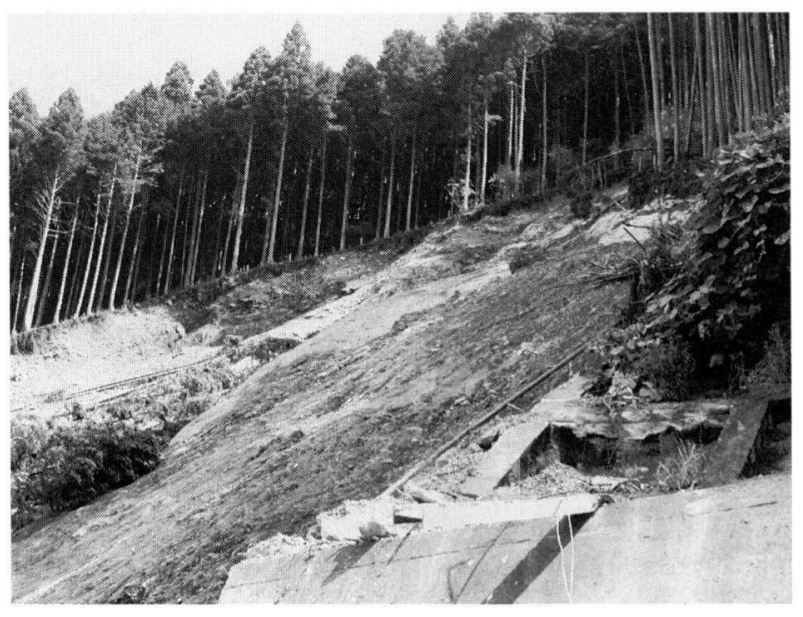

写真一 3 斜面に向かって右側の滑落面の様子（H16.8.14）

Photo. 3 Slide surface on the right side when facing the slope (August 14th, 2004)

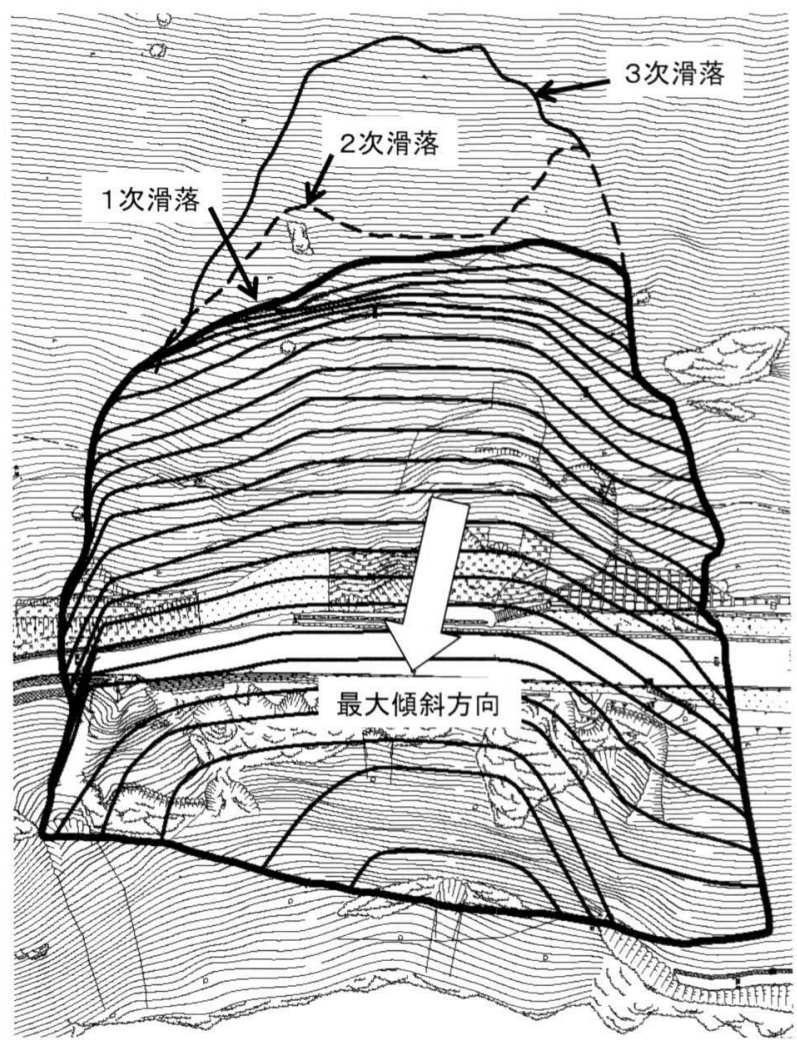

図ー9 1 次滑落ブロックのすべり面コンター図

Fig. 9 Sliding surface contour map of first collapse block 
りブロックの末端部については，小崩壊が確認されてい た斜面下方中央部（図一 6 参照）と推定していた。側部 に関しては，多数の亀裂から地すべりブロック境界位置 を判断していた。図ー6からも分かるように，これらブ ロック範囲の推定は概ね滑落範囲と一致していることが 分かる。末端部については堆積土砂により断定できない が, 移動土塊量, 滑落直前の証言等から推定は妥当で あったと考えられる。

\section{2 すべり面について}

滑落跡で見られるすべり面の上部は概ね平面形を呈し ている $($ 写真 -3$)$ 。滑落部の側部境界付近は, 斜面に 向かって右側部が緩やかな左下方向に傾斜するすべり面 になっているのに対して，斜面に向かって左側部は切り 立った滑落崖を呈していた。滑落後の状況から作成した すべり面コンタ図を図ー 9 に示す。地すべりブロックの 横断面形状は斜面に向かって右側がやや薄く左側がやや 厚い船底型構造であったことが分かる。

\section{3 滑落斜面の周辺の踏查結果}

滑落部の斜面に向かって右側上方の斜面には，滑落部 を取り囲む形で勾配の凹凸等の微地形が見られた。また， 露出したすべり面には, 全体として最大傾斜方向が右上 から左下へ向かう構造も確認できる(図-9)。これら のことから，この部分に新たな地すべりが発生する可能 性がある。また，滑落頭部から尾根にかけての斜面にお いても，いくつかの勾配の凹凸等が確認できたが，この 変状も地すべり性のものであると考えられる。これらの 箇所については伸縮計等により長期的な監視を継続して いくことが必要である。

\section{5．地すべり災害のリスクマネジメント}

\section{1 道路管理者の対応}

表ー 1 に滑落に至るまでの主な経緯を示す。道路管理 者である奈良県五條土木事務所では道路擁壁への亀裂を 確認した後，平成16年 2 月から地すべり土塊が滑落する までの間, 綿密な地すべり移動観測を行っている。地盤 伸縮計による警報装置の設置（管理基準：2 時間連続で の $2 \mathrm{~mm} / \mathrm{hr}$ の変位), 警報作動時の職員携帯電話への自 動通報システム，自動観測システムによる事務所からの リアルタイム監視体制の整備，など効率的なモニタリン グ体制を整備した。また，地すべり滑落という最悪の事 態に備えて対岸の迂回路整備を進め，8月9日に開通さ せている。これらの詳細は岡本ら（2005）が報告してい る。

このように綿密なモニタリングを実施した結果，適切 に滑落の危険性を判断し滑落の前日に国道168号並びに 対岸迂回路の通行止めを行って人的被害を出さず被害を 最小限に抑えられたと言える。

\section{2 崩壊予測}

地すべりブロック頭部における地盤伸縮計の変動量を 元に崩壊予測式の適用を行った。斉藤（1968）が提案し
ている 2 次クリープからの概略の崩壊予測式を適用した 結果を図ー10に示す。ここでは60分毎に予測した滑落余 裕時間と実際の余裕時間との差の絶対値（以下，誤差と いう）を示している。滑落 4 日前の 8 月 6 日頃から, 誤 差は実際の余裕時間の低減に比例して減少している。特 に滑落 2 日前の 8 月 8 日頃からその比例関係が明確とな り約 12 時間前に誤差が 1 時間以内に収まる状態となった。 その後，誤差は多少増減し 2 時間前から滑落にいたるま で一定して45分以内となった。なお，今回の大塔村地す ベりに対する道路管理にも 2 次クリープによる崩壊予測

\section{表ー 1 これまでの主な経緯 \\ Table 1 Major past events}

\begin{tabular}{|c|c|}
\hline 1月下旬 & 国道168号斜面付近に龟裂を発見。 \\
\hline 2月10日 & 山林斜面上4笛所の刍裂部に伸縮計を設置。错測所建設。 \\
\hline 5月3日 & 幅約 $10 \mathrm{~m}$ 高さ約 $5 \mathrm{ml}$ に渡り国道脇山側斜面で表屬崩填発生。片側交通規制実施。 \\
\hline 6月20、21日 & 台風6号に伴う豪雨の影響で㩲壁・法枠等の構造物に盘裂が新たに発生、拡大。 \\
\hline 6月24日 & 午後9時13分、警報機が作動し国道通行止め。 \\
\hline 6月25日 & 午前6時、通行止め解除。 \\
\hline 6月27日 & 河川側擁壁にも梙裂発生。国道から50m上部の斜面に新たな変状発生。 \\
\hline 7月5.6日 & 土木研究所の藤澤上席研究員が現地踏査実施、講評。 \\
\hline 7月13日 & 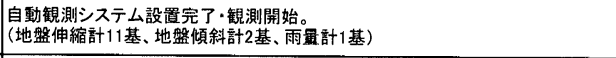 \\
\hline 7月28日 & 災害事前協議。 \\
\hline $\begin{array}{l}\text { 7月31日 } \\
\text { 8月1日 }\end{array}$ & $\begin{array}{l}\text { 台風10号の接近に伴い、地すべりが活発化。 } \\
\text { 対虑要員2名を配置。 }\end{array}$ \\
\hline 8月5日 & 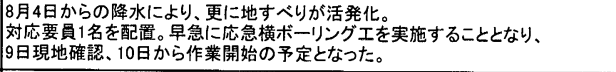 \\
\hline 8月6日 & 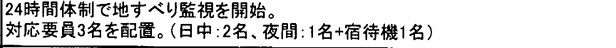 \\
\hline 8月7日 & 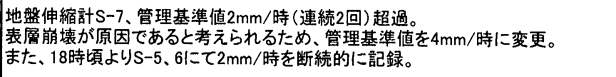 \\
\hline 8月8日 & 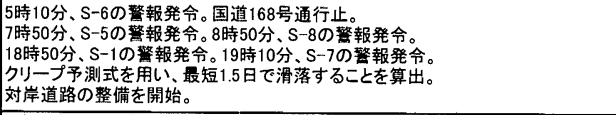 \\
\hline 8月9日 & 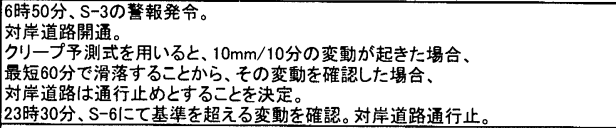 \\
\hline 8月10日 & 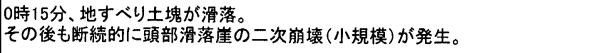 \\
\hline 8月12日 & 22時30分、三次崩壊発生。 \\
\hline
\end{tabular}

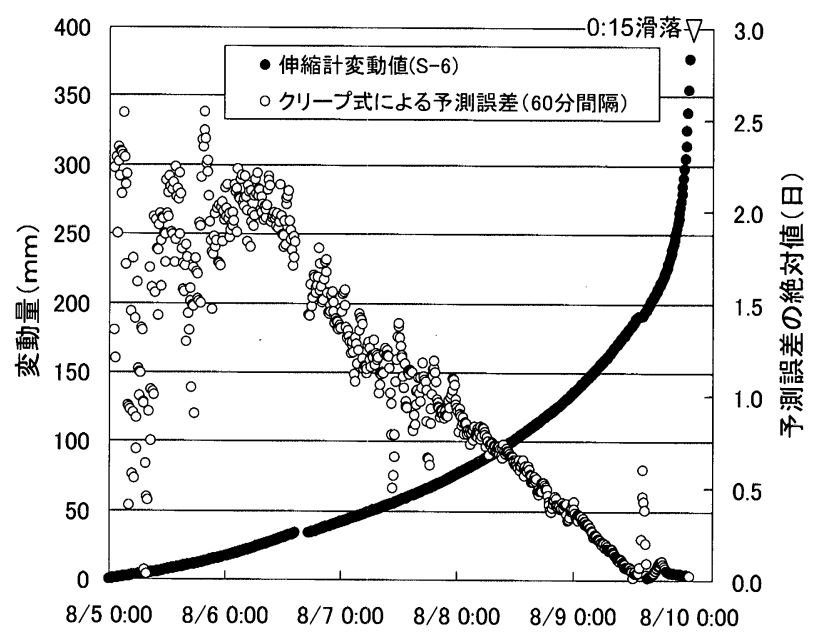

図ー10 クリープ式による崩落予測の誤差

Fig. 10 Error between the time of slope failure and forecast results by creep curves 
式が用いられている。

次に, 福备（1985）が提案している伸縮計変動速度の 逆数による方法を適用した結果を図ー11に示す。滑落 24 時間前では值がばらついているが滑落 6 時間前頃から值 のばらつきが収まり,1本の直線上に収束し始める。これ は地すべりの滑落直前に見られる一般的な特徵である (藤田, 2000)。ここでは特に值が直線上に収束し始めた 滑落約 2 時間半前から約 1 時間のデー夕による近似直線 を予測に用いた。なお，この間の伸縮計変位速度は約 18 $(\mathrm{mm} / \mathrm{h})$ であった。この予測の結果, 誤差は 1 分以内 となり, 滑落約 1 時間半前には滑落時刻をほぼ誤差なく 予測できた。本地すべりの場合, 滑落直前の地すべり末 期においてこの方法の滑落予測精度は非常に高い結果と なった。

以上のように滑落予測式が比較的良く適用できた理由 としては, 今回の地すべりが層理面に沿った流れ盤構造 ですべり面も概ね直線的な形状であったため破壊経路が 一般的なクリープ破壊の経路を辿ったことが考えられる。 しかし，明確な適用基準は確立されておらず，地すべり の地形・地質的特性や降雨等の気象条件によっては予測 誤差が大きくなることもあり, 計算結果を崩壊予測の参 考程度に留めるのが一般的である。

\section{3 リスクマネジメント手法の検討}

ここでは，上野（2005）が整理しているように, 発生 が予想される被害の防止を主眼とする活動を「リスク管 理」, 発生後の被害の最小化と原状復帰を行う活動を「危 機管理」, そして両方合わせたものを「リスクマネジメ ント」と定義する。

一般的な土砂災害の「リスク管理」実施フローがNational Research Council（2004）によって推奨されてお

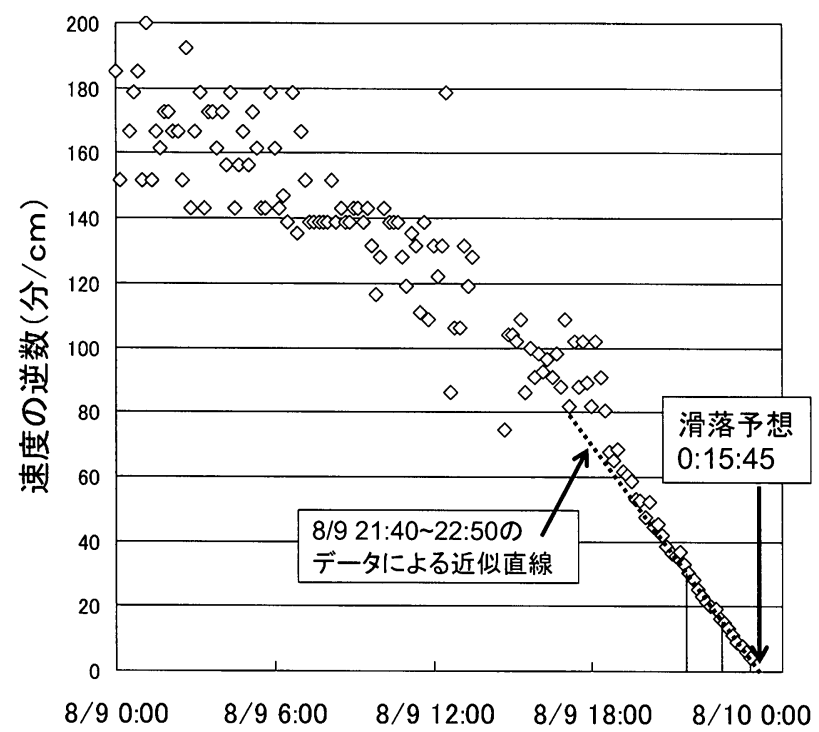

図一11 伸縮計変位速度の逆数による崩落予測結果

Fig. 11 Application results of inverse number of velocity of extensometer displacement to forecast the time of slope failure
り，それに多少修正を加えたものと奈良県大塔村の事例 を元に独自に検討した「危機管理」実施フローを組合せ， 地すべりの「リスクマネジメント」実施フローを図 -12 のように示す。ここで示した「リスク管理」実施フロー はある広域の対象地域において土砂災害の発生確率（頻 度）とその被害想定からリスクに対する適切な対応を検 討するものである。図ー12において，今回取り上げた宇 井地区地すべりの災害対応は「危機管理」である。この 「リスクマネジメント」フローで重要なのは，「危機管理」 の「対応の検証」結果を災害に対する事前の「リスク管 理」に反映させることである。事前の「リスク管理」の 中には「危機管理」の際に重要な「危機対応マニュアル」 の策定，更新も含まれる。今回の「危機管理」の経験を 元に広域的範囲での事前の「リスク管理」を行い，総合 的「リスクマネジメント」に慗げることで効率的に地域 のリスクを低減させることが可能になるという考え方で ある。

フローにもあるように「リスク評価」には災害の発生 確率が必要となる。地すべり災害の場合，各箇所の災害 発生確率は一般的に極めて低く，またそれを定量的に算 出する手法は示されていない。しかし，今回の国道168 号のように山間部の道路の場合，迂回路が少なく長距離 区間を一体として保全しないと意味がなく一連の管理区 間のどこか 1 箇所で地すべり災害が発生する確率をその 地域の過去の履歴等から算出することで，リスクの試算

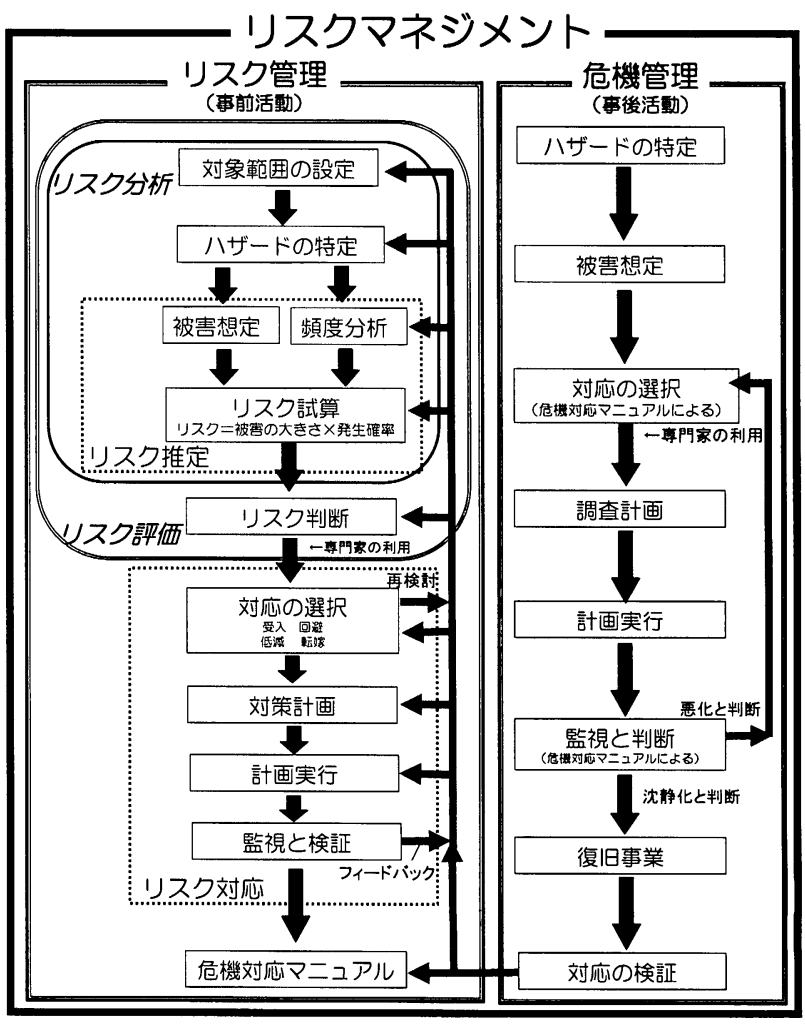

図一12 リスクマネジメント検討プロセスの概略 Fig. 12 Schematic illustration of landslide risk management decision processes 
を行うことが可能であると考えられる。今後具体的に検 討すべき課題である。

\section{4 地域観光経済への影響}

大塔村地すべり災害が周辺の観光産業にどの程度影響 を与えたかを検討した。被災した国道168号線は十津川 温泉郷への主要ルートであり, 十津川温泉郷周辺へはこ のルートを通って関西都市部からの観光客が多く訪れる。 近畿運輸局等 (2003) の推計では熊野古道の世界遺産登 録にともない2001年比で観光客数 1 割増が見込まれてい た。見込み観光客数と 2004年実績観光客数との差から観 光客消費（地域観光収入に相当）の低減額を試算した。 宿泊客数は十津川村観光協会調查結果を用い，十津川温 泉, 温泉地温泉, 上湯温泉, 赤谷オートキャンプ場, 星 のくに等を対象とし，日帰り客数は十津川温泉郷を対象 とした。また, 観光客 1 人あたりの消費単価は平成14年 度の日本観光協会調査結果の奈良県平均值を代用した。 試算した結果を表 -2 に示す。平成16年の観光客消費に は世界遺産登録に伴う推計值から15億円弱下回っている ことが分かった。これは同様の手法で推計した十津川温 泉郷周辺全体の見込み観光消費量の $25 \%$ 以上となる。こ こで試算した損失額はあくまで単純比較に基づく推計で あり,この結果を直ちに詳細な議論に用いることは出来 ないが, 本地すべりが周辺地域にかなり大きな影響を与 えていることを示していると考えられる。

この結果について注目すべきは, これが道路通行途絶 による直接的な被害ということではなく，その多くは次 に述べるとおり, 風評被害等の間接的被害であるいうこ とである。大塔村の地すべり災害に際して片側交通規制 は暫時行っていたものの, 滑落前に迂回路は整備されて おり完全にこの区間の交通が止められたのは滑落直前と 豪雨時の実質 5 日間のみである。マスコミよって関西地 区を中心に繰り返し報道された地すべり移動映像によっ て地すべりの恐ろしさだけが強調され, 全面通行止めに なっていると認識した，もしくは周辺での更なる崩落の 危険性を心配した観光客が多くいた結果であると考えら れる。地元の奈良新聞（2004年12月22日朝刊第 1 面）で も「テレビで何百回と放映され，怖さだけをあおった」 問題点について指摘されている。リスクマネジメントに おいて，正確な情報をどう伝えていくかということも重 要なファクターになると言え, 図ー12に打ける「リスク 管理」の「危機対応マニュアル」等に予め対応方針を定 めておくべきである。

\section{5 地すべりの変位速度と社会的影響}

3.で述べたように本地すべりも一般的な地すべり同 様，概ねクリープ理論に合った運動特性を示した。そし て滑落時には 3 次クリープ状態における最大変位速度 18 $(\mathrm{mm} / \mathrm{h})$ の約 $7 \times 10^{5}$ 倍にあたる約 $3.5(\mathrm{~m} / \mathrm{s})$ で高速移 動した。このように変位速度が時間をかけて大きく変化 する地すべりでは, 変位速度のレベルごとに社会へ及ぼ す影響は異なると考えられる。ここでは過去の地すべり
災害事例や上野（2005）の整理結果を参考に，考えられ る社会的影響の例について表-3のように列挙してみた。 地すべりによる直接的影響は運動状態が極めて活発で継 続時間の比較的短い II， IIIに発生しやすいが，間接的影 響は運動状態は緩慢であるが継続時間の比較的長い I, IV どの状態でも発生する傾向が見られた。このことは, 長期化することの多い地すべり運動においては，間接的 影響が長期に渡り発生しやすいことを示唆している。

間接的被害の評価手法については，アンケートを通じ た実証的研究が行われているに留まり（例えば，広井ら， 1986), 定量的評価手法は確立されていないのが現状で ある（例えば，損害保険料率算定会，1997）。今後 1つ でも多くの間接的影響の実態を把握し影響評価期間の検 討も含めた評価手法を確立することによって，図ー12に 示したリスクマネジメントのフローに扔ける「リスク管 理」の「リスクの推定」部分と「危機管理」の「被害想

表一2 地すべり災害による十津川温泉郷の観光損失額推計

Table 2 Loss estimation on sightseeing in Totsukawa hot spring village caused by the landslide event

\begin{tabular}{|c|c|c|c|}
\hline & $\begin{array}{l}\text { 宿泊客数 } \\
\text { (A) }\end{array}$ & $\begin{array}{l}\text { 入込み客数 } \\
\text { (B) }\end{array}$ & $\begin{array}{c}\text { 日帰り客数 } \\
(B-A)\end{array}$ \\
\hline $\begin{array}{c}\text { 平成13年度実績 } \\
\text { (C) }\end{array}$ & 81,020 & 362,712 & 281,692 \\
\hline $\begin{array}{c}\text { 平成16年度推計 } \\
(C \times 1.1)\end{array}$ & 89,122 & 398,983 & 309,861 \\
\hline 平成16年度実績(D) & 57,532 & 335,595 & 278,063 \\
\hline $\begin{array}{c}\text { 平成16年度 } \\
\text { 観光損失 } \\
(C \times 1.1-D: E)\end{array}$ & 31,590 & - & 31,798 \\
\hline
\end{tabular}

\begin{tabular}{|c|c|c|c|}
\hline & 宿泊客 & - & 日帰り客 \\
\hline $\begin{array}{c}\text { 観光消費単価 } \\
\text { (奈良県平均:F) }\end{array}$ & 39,070円/人 & - & 7,900円/人 \\
\hline $\begin{array}{c}\text { 観光消費損失額 } \\
(\mathrm{E} \times \mathrm{F})\end{array}$ & $1,234,221,300 円$ & - & $251,205,780 \mathrm{P}$ \\
\hline 総観光消費損失額 & \multicolumn{3}{|c|}{$1,485,427,080$ 円 } \\
\hline
\end{tabular}

表ー3＼cjkstart地すべりの運動区分とそれに伴う被害 Table 3 Landslide movement Influence on disaster damage

\begin{tabular}{|c|c|c|c|c|c|c|}
\hline \multirow{2}{*}{ 地すべりによる被害の種類 } & \multirow{2}{*}{$\begin{array}{l}\text { 直接的 } \\
\text { 影響 } \\
\end{array}$} & \multirow{2}{*}{$\begin{array}{c}\text { 間接的 } \\
\text { 影鄉 }\end{array}$} & \multicolumn{4}{|c|}{ 運動区分 } \\
\hline & & & $\mathrm{I}$ & II & III & IV \\
\hline 施設·家屋の破壊 & $\overline{0}$ & & & 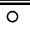 & 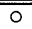 & \\
\hline 人命(変状として崩壊·落石は発生する) & 0 & & & 0 & 0 & \\
\hline 農作物·木材被害 & 0 & & & 0 & 0 & \\
\hline 河道閉塞に湛水・土石流被害 & 0 & & & & 0 & 0 \\
\hline 多ムからの段波、オーバーフロー & 0 & & & & 0 & \\
\hline 採石制限 & 0 & & & 0 & 0 & 0 \\
\hline 地すべりによるダム利用制限 & & 0 & 0 & 0 & & \\
\hline 風評被害 (過度の危険意識·情報伝達不足) & & 0 & & 0 & 0 & 0 \\
\hline 地域産業の哀退 & & 0 & & & & 0 \\
\hline 周辺地価の下落 & & 0 & 0 & 0 & 0 & 0 \\
\hline 住民避難·不安感の增大 & & 0 & 0 & $\mathrm{o}$ & & \\
\hline 生活の立て直しまでの苦痛 & & o & & & & 0 \\
\hline 管理者の負担增大(通常業務へ影響) & & 0 & 0 & 0 & 0 & $\circ$ \\
\hline 隔離危険地域住民の不安感の增大 & & 0 & & 0 & 0 & 0 \\
\hline \begin{tabular}{|l} 
迁回時間賣失 \\
\end{tabular} & & $\mathrm{O}$ & & $\mathrm{o}$ & o & 0 \\
\hline 鉄道不通代替輸送䪱失 & & 0 & & 0 & 웅 & 0 \\
\hline 「イフライン寸断で生活へ影響(電気·通信、行政サービス) & & o & & 0 & 0 & 0 \\
\hline
\end{tabular}

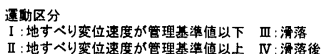


定」部分を拡充し実態に即したフローとしていくことが 求められる。

\section{6. まとめと課題}

平成16年 8 月に発生した奈良県大塔村地すべり災害を 事例として，地すべりの運動特性を明らかにするととも にリスクマネジメント手法の適用を試みた。その結果を 以下にまとめる。

・地すべり変状の発見から緩慢な動きを繰り返しながら 6 ヶ月以上経って地すべり土塊は滑落したが，その間， 自動監視システムの導入や職員の常駐化による適切な 危機管理が行われ被害を最小化出来たと考えられる。

- 今回滑落した箇所の上部周辺にも地すべり变状は散見 され，道路復旧作業に際しては不安定箇所のモニタリ ングを行うことで作業の安全性を確保しながら行う必 要があるため, 復旧には 3 年間程度の長期間を要する。 地すべり災害の影響が長期化することを示す例である。 ・地すべり災害について一般的に行われている危機管理 は，災害発生からの短期的対応に止まっており，現状 のリスクマネジメントには中長期的な事前のリスク管 理の視点が欠けている。地すべり災害の社会に与える 影響を最小化するためには，危機対応の経験をさらに 事前のリスク管理へフィードバックしていくことが必 要である。

・地すべり災害の周辺地域経済への間接的影響を観光収 入について試算した結果，平成 16 年の 1 年間で約 15 億 円もの損失が推計された。長期化することの多い地す ベり災害では社会に対する直接的な影響だけでなく間 接的な影響も看過できないことが実証的に示された。

・過去の事例より考えられる地すべり災害の社会的影響 とそれが見られる運動状態について例示してみた結果， 間接的影響は速度が緩慢もしくは滑落後にも渡って長 期間発生する傾向にあり, 地すべりの長期化する運動 特性に起因していると考えられる。

今後，地すべり災害の社会的影響の全容把握と間接的 な影響の評価手法の開発が課題となる。統計学的, 経済 学的アプローチにより体系的に整理していく予定である。

最後になりましたが，本稿をまとめるにあたり，奈良 県五條土木事務所の方々にはご多忙の中, 資料提供等多 大なるご協力を賜わりました。ここに記して深く感謝申 し上げる次第です。

\section{参考文献}

国土交通省砂防部 (2005)：ホームページ，http://www.mlit.go.jp /river/sabo/main.htm

池田三郎（2000）：リスク対応の戦略, 政策, 精度, リスク学辞典, $310 \mathrm{p}$.

龟田雄二・低引洋隆・小橋澄治・水山高久（2003）：土砂災害にお けるリスクマネジメント, 平成14年度砂防学会研究発表会概 要集, pp. $164-165$.

小橋秀俊 (2003)：岩盤・斜面崩壊に対する合理的なりスク評価手 法の開発, 平成15年度日本地すべり学会関西支部シンポジウ ム, pp. $39-49$.

高橋健二・大津宏康・大西有三（2003）：タンクモデル法を用いた 地下水位変動挙動を考慮した斜面リスク評価の研究, 土と基 礎, Vol. 51, No.10, pp. 15-17.

鈴木将之・石井靖雄・藤澤和範（2005）：降雨指標による地すべり 警戒基準に関する調查（第 1 報），土木技術資料，Vol. 42 , No. 2, pp. $52-57$.

日本地すべり学会（2002）：日本の地すべり一第 6 版一，7p.

Robert L. Shuster (1978) : Economics of slope movements, Landslides Analysis and Control, National Academy of Sciences, 3 p.

建設省土木研究所 (1999）：平成10年度地すべり危険箇所調査.

斉藤迪孝（1968）：斜面崩壊発生時期の予知に関する研究，鉄道技 術研究報告, No. 626, 日本国有鉄道鉄道技術研究所, 53p.

藤澤和範 - 野村康裕 - 小山内信智 - 池田 正 - 谷口房一 (2004)： 奈良県大塔村で発生した地すべり災害（続報），土木技術資料， Vol. 46, No. 10, pp.4-9.

David J. Varnes (1978) : Slope Movement Types and Processes, Landslides Analysis and Control, National Academy of Sciences, 23p.

近畿地方整備局（2004）：ホームページ，http://www.kkr.mlit.go. jp/plan/2004-jisuberi-0810/

岡本清介・岡田力俊・牧田孝光 (2005): 大塔村宇井地区地すべり による道路災害と監視体制について，平成17年度日本地すべ り学会シンポジウム, pp. 22-29.

福直輝旗（1985）：表面移動速度の逆数を用いた降雨による斜面崩 壊発生時刻の予測法, 地すべり, Vol.22, No.2, pp. 8-13.

藤田壽雄（2000）：研修ガイダンスのための地すべり概論，地すべ り防止技術研修テキスト上巻, 地すべり対策技術協会, pp. 1 -49 .

上野雄一 (2005) : 斜面災害のリスクマネジメント（その1), 地 すべり技術, Vol. 31, No. 3, pp. 15-25.

National Research Council (2004) : Partnerships for Reducing Landslide Risk, 56p.

近畿地方整備局・近畿運輸局 - 近畿農政局 - 近畿経済産業局 （2003）:「紀伊山地の霊場と参詣道」の世界遣産登録にかかる 地域経済活性化調查報告青.

広井脩代表（1986）：災害の及ほすす社会的影響, 文部科学省研究费 補助金自然災害特別研究研究成果，No.59020015，60020021 損害保険料率算定会 (1997)：火山災害の研究，地震保険調查研究 $42,264 \mathrm{p}$.

（原稿受付2005年 8 月29日，原稿受理2006年 1 月 5 日） 